\title{
地すべり地形分布と地質との関係 Relationship between Landslide Distribution and Geological Units
}

\author{
土志田正二 ${ }^{a) *}$ \\ Shoji DOSHIDA
}

\begin{abstract}
Many landslides occur in places where landslides had been generated in the past, or in the immediately surrounding area. For prevention and mitigation of landslide damage, it is very important to create landslide inventory maps that show the locations of past landslides. Therefore, the National Research Institute for Earth Science and Disaster Prevention (NIED) in Japan, has published “Landslide Distribution Maps". These maps include more than 380, 000 landslide topographies covering all of Japan, produced by interpretation of aerial photographs.

However, the landslide distribution throughout Japan is not balanced; there are density differences. We propose a method of wide area landslide assessment that uses the features and distributions of a specific geological setting. We calculate the landslide body ratio for each geological unit. This ratio is the rate of the landslide body area in each geological unit to the entire area of that geological unit. The results show that the landslide body ratio differs greatly from one geological unit to the next.

Key words : Landslide, Landslide distribution map, Geological unit, Landslide body ratio

\section{和文要旨}

地すべり災害は，過去に地すべりが発生した山体斜面，もしくはその周辺で起こり易いことが知られている。そのため過去に地 すべりが発生したと思われる地形，いわゆる「地すべり地形」を判読・記載した地すべり地形分布図は，将来の地すべり災害予測 のための基礎デー夕となり得る。本研究では, 日本全国で38万箇所以上の地すべり地形が判読されている防災科学技術研究所の地 すべり地形分布図を用いて，地すべり地形の広域的な分布傾向を定量的に評価する手法の開発を行い，地すべり地形分布と地質と の関係性について明らかにすることを試みた。地すべり地形分布を定量的に表すための手法として考案したのが，任意の空間領域 内における地すべり移動体の占める割合を算出した「地すべり移動体面積率」である。地質情報を基に，各地質分類に打ける地す ベり移動体面積率を算出した結果，各地質における地すべり移動体面積率は大きな密度差があることが示された。 キーワード：地すべり, 地すべり地形分布図, 地質, 地すべり移動体面積率
\end{abstract}

\section{1.はじめに}

一度地すべりを起こした山体斜面は，変形・破壊を受 けるとともにすべり面が形成されているため，他の山体 斜面と比べて地すべりが繰り返し発生し易くなっている。 （1997年に発生した澄川地すべり（大八木・池田， 1998 ；井口，1998）など多数の事例有り)。また地すべ りを起こした斜面近傍も，すべり面を形成しやすい地質 構造を持っていると推測されるため，地すべりが発生す る危険性が高い（土志田，2012）。過去に地すべり変動 を起こした斜面は「地すべり地形」と呼ばれ，その分布 や地形特性を明らかにすることは，過去の地すべり災害 の発生場を明らかにするだけではなく，将来の地すべり の発生危険度を評価するためにも重要である。

地すべりの発生形態・発生機構は様々である（日本地 すべり学会，2004）が，地下深くにすべり面を形成する ことが多い地すべりは，地質に強く影響を受けているこ とが定性的に知られている。地すべりと地質との関係に ついては，黒田（2002）などでも考察されているが，そ の内容は個々の地質における地すべり形態の差異につい て述べられているものであり，地すべりと地質との関係 についてのその他の先行研究に打いても同様である。地

* 連絡著者/corresponding author

a) 総務省消防庁消防大学校消防研究センター研究官/国立研究開発法人防災科学技術研 究所客員研究員

National Research Institute of Fire and Disaster, Japan/National Research Institute for Earth Science and Disaster Prevention 厂182-8508 調布市深大寺東町 $4-35-3$
質における地すべり地形の分布密度についての研究も行 なわれているがそのほとんどは定性的な研究であり，定 量的な研究も四国（土志田・井口，2010）や北海道（山 岸，2012）などの一部地域を対象として行われているも ののみであった。このように，地すべり地形の分布と地 質との関係について，広域を対象として定量的に示した 研究はほとんどない。本研究では，防災科学技術研究所 （以下，防災科研とする) が判読・刊行を行っている縮 尺 5 万分の 1 地すべり地形分布図（防災科研，2015）と 産業技術総合研究所（以下，産総研とする）が公開して いる20万分の 1 日本シームレス地質図（産総研，2014） とをGIS（Geographical Information System）を用いて 空間解析を行うことで，日本全国における地すべり地形 と地質との関係について定量的に表すことを目的とした。

\section{2. 使用データ}

\section{1 防災科学技術研究所の地すべり地形分布図の特徴}

本研究で用いた地すべり地形GISデー夕は, 防災科研 から刊行されている地すべり地形分布図（防災科研, 2015）である。防災科研の地すべり地形分布図は2015年 3 月現在, 本州・四国・九州・北海道とほぼ日本全域で 判読が完了しており，図一 1 で示した範囲においては判 読のみならずGISデー夕も作成が完了し，ホームページ においても公開されている（灰色部分は未判読地域，も しくは判読はされているが地すべり地形がGISデー夕化 


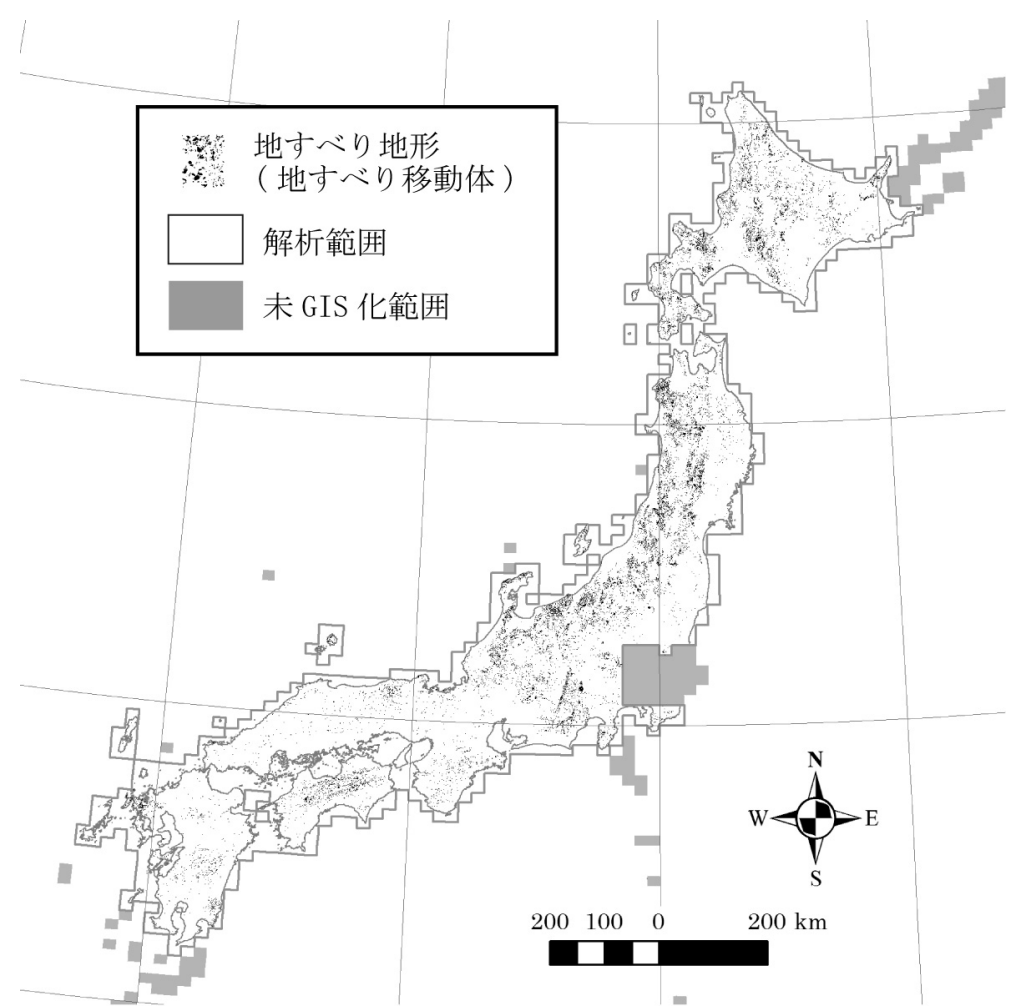

図一 1 地すべり地形分布図 (防災科研) と本研究の解析範囲

Fig. 1 Landslide Distribution Maps(NIED) and study area

されていない地域を示す)。地すべり地形の判読は，基 本 4 万分の 1 縮尺の空中写真を用いて完全に手動で個々 の地すべり地形ごとに行われている（清水，1983，大八 木，2007）。地すべり地形分布図の刊行は昭和56（1981） 年度に開始され，最新の地すべり地形分布図第57集「沖 縄県域諸島」(防災科研，2014）は平成26年（2014） 3 月 に刊行されるなど，その判読の歴史は33年以上にも及び, 判読数及び判読エリアは世界でも類を見ない貴重なデー 夕となっている。本研究では，地すべり地形がGISデー 夕として公開されている枠内の範囲における陸域を解析 対象地域として研究を行った。判読された地すべり地形 の数は 38 万箇所を超えているが，判読は幅 $150 \mathrm{~m}$ 以上の 地すべりを対象としているため, 表層崩壊などの小規模な 斜面崩壊地形は含まれていないことは注意が必要である。

防災科研の地すべり地形分布図のGISデータは，地す ベり移動体（ポリゴンデータ）, 地すべり滑落崖（ポリ ラインデータ), 地すべりの移動方向・形態（ポイント データ，一部の地すべりにのみ付与されている）から形 成されている。地すべり滑落崖（ポリラインデータ）, 地すべり移動方向・形態（ポイントデータ）は面積情報 を持たないため本研究での解析では使用せず，面積情報 を持つ地すべり移動体ポリゴンデー夕のみを使用した。

\section{2 産業技術総合研究所の20万分の 1 日本シームレ ス地質図}

本研究で使用した 20 万分の 1 日本シームレス地質図は 2015年 3 月現在，日本全域を網羅する既存の地質情報の 中で最も解像度の高いデータである。20万分の 1 日本
シームレス地質図は基本版，詳細版に分かれており，本 研究では詳細版の地質デー夕を用いている。詳細版の地 質データは，日本全国の地質を347種に分類したもので あり，GISを用いて簡単に解析することができる形式 （シェイプ形式）で公開されているため，本研究におけ る空間解析に相応しいデータである。

20万分の 1 日本シームレス地質図のGISデータの特徵 として，地質領域をポリゴンデータ，地質境界やその他 地質構造をポリラインデータとして作成されている。本 研究における解析は面積の空間比較を行うこともあり, 地質領域のポリゴンデータのみを使用している。

\section{3. 解析方法一地すべり移動体面積率の算出}

地すべり地形分布図における地すべり移動体GISデー 夕（ポリゴンデータ）を，広域を対象として解析に用い る場合には大きな問題点が 2 点存在する。 1 点目は地す ベり移動体GISデータ（ポリゴンデータ）はシームレス 化されていないという問題である。地すべり移動体GIS データは20万分の 1 図幅ごとに区切られて作成・公開さ れているため，図幅をまたがって分布している地すべり 移動体は図幅線に沿って分割されてしまっている。また 刊行されている地すべり地形分布図（紙媒体）は 5 万分 の 1 図幅で作成されていることから,5万分の 1 図幅の境 界においても地すべり移動体の接合が十分に取れていな い場合もある。この図幅境界の問題は，日本全域という 広域においては個々の地すべり移動体の面積を用いて議 論を行うことが難しいことを示す。 2 点目は判読期間が 
30年以上と長期間であったことから，その期間における 地すべり判読技術の向上である。地すべり判読技術の向 上によって，初期は 1 つの大きな地すべり移動体ブロッ クとして判読されていた地すべり地形が，徐々に複数の 小さなブロックに分割してより詳細に判読されるといっ た傾向が見られる。この問題も日本全域のような広域を 対象とする場合には，個々の地すべり移動体の面積を用 いた議論をすることを更に難しくしている。本研究では 以上の問題を解決するため, 個々の地すべり移動体の面 積ではなく，任意の領域内における地すべり移動体の占 める割合，「地すべり移動体面積率」を算出することで 全体的な傾向を把握し議論を試みた。「地すべり移動体 面積率」の算出方法は以下の通りである。

\section{[地すべり移動体面積率 $]$ \\ $=[$ 任意の領域における地すべり移動体の総面積 $] /$ \\ [任意の領域の全体の面積］}

「地すべり移動体面積率」を用いることで，個々の地 すべりが20万分の 1 図幅ごとに区切られている場合や， 1 つの大きな地すべり移動体ブロックが複数の小さなブ ロックとして判読されている場合においても，計算結果 に与える影響を最小限にすることができ，任意領域同士 の地すべり移動体面積の比較を行うことができる。

また本研究では日本全域を対象とし面積比較を行うこ とから，経緯度による面積差が出ない投影法であるラン ベルト等積円筒図法（正積円筒図法）に全てのデー夕を 投影変換してから解析を行った。本研究で用いたランベ ルト等積円筒図法は, 中央経線 0.0 度, 標準緯線 0.0 度で 設定されており，世界測地系WGS1984を適用している。

\section{4. 結果・考察}

\section{$4.11 \mathrm{~km}$ 四方の地すべり移動体面積率 $\left(1 \mathrm{~km}^{2}\right)$}

図一 2 に $1 \mathrm{~km}$ 四方における地すべり移動体の占める 割合を算出した地すべり移動体面積率図を示す。ここで 算出した地すべり移動体面積率は，地すべり移動体面積 率 $\left(1 \mathrm{~km}^{2}\right)$ と記載する。この $1 \mathrm{~km}$ 四方の地すべり移 動体面積率 $\left(1 \mathrm{~km}^{2}\right)$ は, 解析領域及び地すべり移動体 ポリゴンを前述したランベルト等積円筒図法に変換した 後に $50 \mathrm{~m}$ メシュデータに変換し, $20 セ ル \times 20 セ ル （ 1$ km四方）内の地すべり移動体メッシュデータの占める 割合を算出した。この結果, 本研究に扔ける解析範囲内 の地すべり移動体面積率 $\left(1 \mathrm{~km}^{2}\right)$ の平均值は $5.2 \%$ で あった（解析範囲の地すべり移動体の総面積（18, 559.7 $\left.\mathrm{km}^{2}\right)$ ，解析範囲全体の面積 $\left.\left(353,536.2 \mathrm{~km}^{2}\right)\right)$ 。従来の 研究では，地すべり（及び崩壊）の分布量を表す際には, 崩壊密度（単位面積あたりの崩壊の個数）を使用するこ とが多かったため，この地すべり移動体面積率の示す值 (平均值 $5.2 \%$ ) の多宑について言及するのは難しいが, 経験的には高い印象を受ける。図-2の凡例は，この全 体の平均値を用いて，その半分の值 $2.6 \%$, 平均値 $5.2 \%$,
倍の值 $10.4 \%$ ，更にその倍の值（平均值の 4 倍） $20.8 \%$ を区切りとして,5段階に地すべり移動体面積率（1 $\mathrm{km}^{2}$ ）を分類しており，相対的な地すべり移動体面積率 $\left(1 \mathrm{~km}^{2}\right)$ の差を図化した。この結果，東北日本の日本 海側で地すべり移動体が多く，西日本中国地方の日本海 側で地すべり移動体が少ないなど，図ー1のような単純 に地すべり地形分布を示した図と比べると，地すべり移 動体分布の密度差をより明瞭に表示することが可能と なった。

図ー2 からは以下のような地すべり地形分布の傾向が 観察される。地すべり移動体面積率 $\left(1 \mathrm{~km}^{2}\right)$ は，糸魚 川－静岡構造線を境とした東日本・西日本で大きな差異 が見られる。東日本においては，北海道中央，東北地方 奥羽山脈より西側にかけて幅広く地すべり移動体面積率 $\left(1 \mathrm{~km}^{2}\right)$ が高い地域が広がるのに対し，西日本では北 陸の日本海に面した地域を除き，中央構造線に沿った地 域，長崎県北松浦半島周辺，宮崎県鰐塚山周辺など線状 もしくは局所的な地域に集中して地すべり移動体面積率 $\left(1 \mathrm{~km}^{2}\right)$ の高い地域が分布している。これらの地すべ り移動体面積率 $\left(1 \mathrm{~km}^{2}\right)$ の違いについて，地質情報を 踏まえることで考察を行った。

\section{2 地質 347 分類の地すべり移動体面積率（地質）}

図-3, 表- 1 は日本シームレス地質図における347地 質分類において，それぞれで地すべり移動体面積率を算 出し，その結果を表示したものである。地質情報を基に 算出した地すべり移動体面積率は，地すべり移動体面積 率 (地質) と記載する。本節の地すべり移動体面積率 (地 質）は4.1節で行ったようにメッシュデータに変換する ことなく，ポリゴンデータをそのまま用いて算出した。 図-3の凡例は図 -2 と同様に，全体平均の $5.2 \%$ 用 いて 5 段階で評価したものである。また各地質分類にお ける地すべり移動体面積率（地質）の算出結果を表 - 1 （1-1〜 1-5）に示しているが，地すべり移動体面 積率（地質）のほか，地質面積，（地すべり）移動体面 積も合わせて記載している。その理由は，地すべり移動 体面積率を算出する際に分母となる「任意の領域の全体 の面積」，つまり「対象地質全体の面積（地質面積）」が 極端に小さい場合には，数少ない地すべり移動体分布で あっても地すべり移動体面積率（地質）に強く影響与え てしまうため，そのデー夕の持つ信頼性が地質面積の大 きい他の地質体と比べて低いことを示すためである。つ まり，表一 1 に記載した地質面積，（地すべり）移動体 面積は，各々の地質に扔ける地すべり移動体面積率（地 質）の信頼性を表す指標として利用することができる。

\section{3 地すべり移動体面積率（ $1 \mathrm{~km}^{2}$, 地質）と地質 の比較}

地すべり移動体面積率 $\left(1 \mathrm{~km}^{2}\right)$ 及び地すべり移動体 面積率（地質）の差異の原因について，地質情報との比 較を行い考察した。北海道中央部において地すべり移動 体面積率（1 km²，地質）の高い地域が分布しているが， 


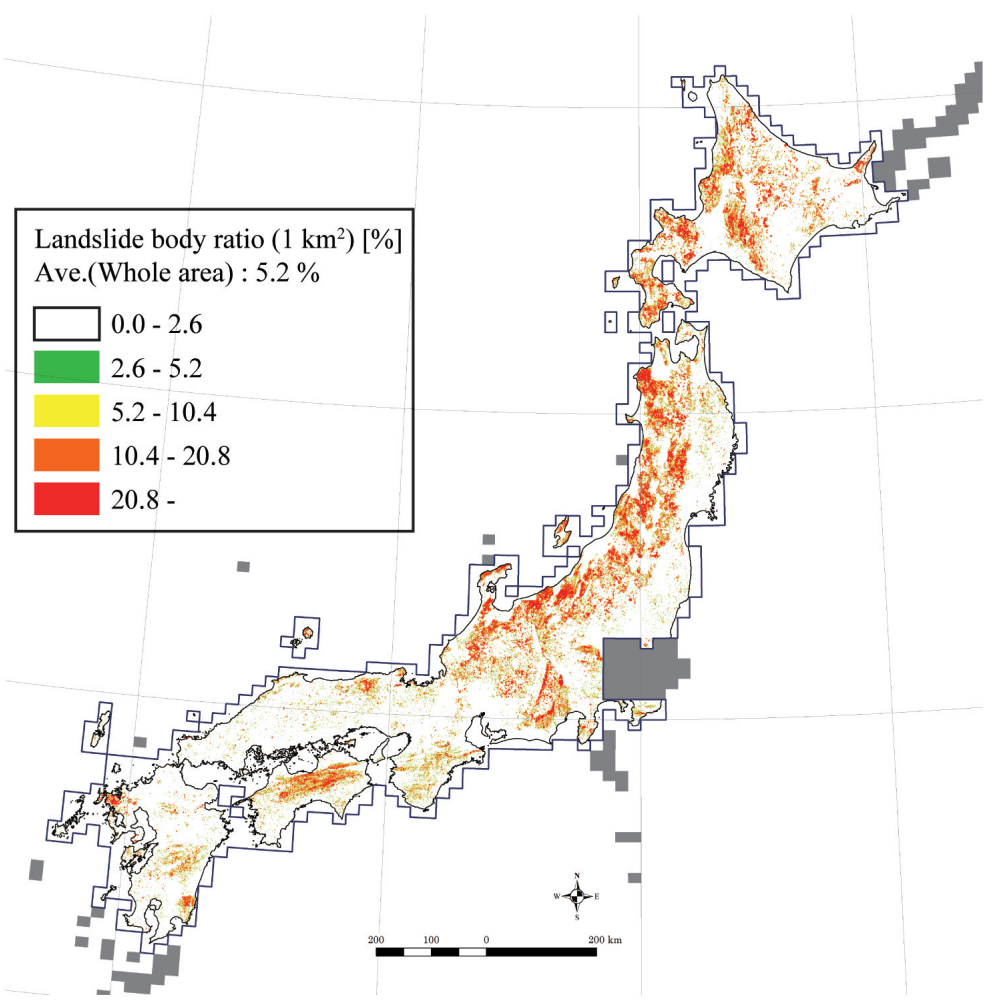

図一2 $1 \mathrm{~km}$ 四方における地すべり移動休面積率 $\left(1 \mathrm{~km}^{2}\right)$ 図 Fig. 2 Landslide body ratio map for each $\mathrm{km}^{2}$

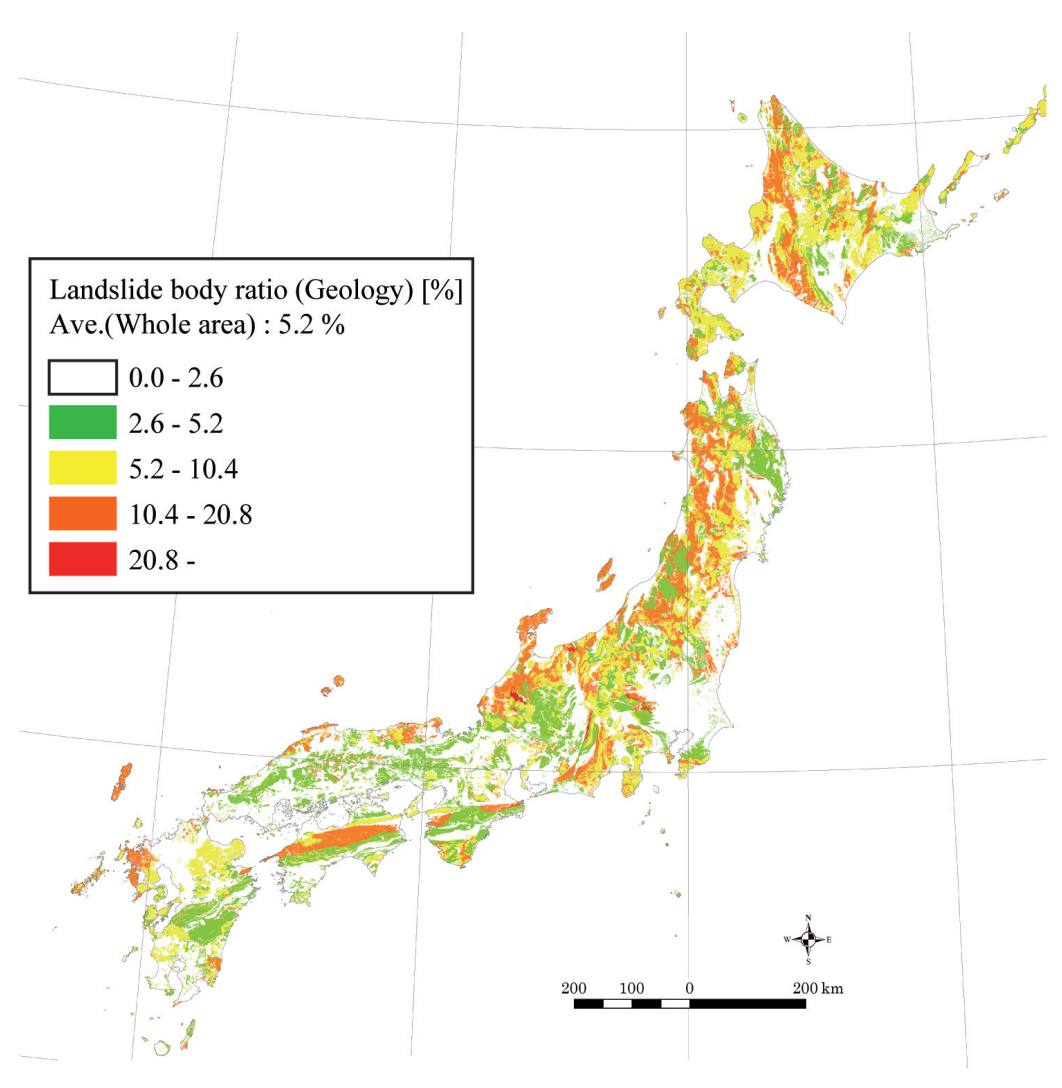

図一３地すべり移動体面積率(地質)図 (347地質分類)

Fig. 3 Landslide body ratio map based on geological units divided into 347 classifications 
この地域は高圧型変成岩類であるカムイコタン変成岩類, 超苦鉄質岩類（蛇紋岩）などが分布していることが原因 だと推定される（鈴木，2006；大八木ほか，2013）。東 北地方奥羽山脈西側においても地すべり移動体面積率 (1 km²，地質）が高い值を示しているが，この地域は 新・古第三紀の堆積岩類が広く分布している。また東北 地方白神山地周辺に扔いては，新第三紀の苦鉄質の火山 岩類も分布しており, この地域も地すべり移動体面積率 （1 km²，地質）は高い。糸魚川－静岡構造線の北側末 端である糸魚川周辺において地すべり移動体面積率（1 $\mathrm{km}^{2}$ ，地質）が高くなっている原因の 1 つとして，超苦 鉄質岩類が分布していることが考えられるが，それと同 時に地殼変動（断層運動）が活発であるという理由も考 えられる(望月, 1977 ; 望月・中村, 1977)。地殼変動が 地すべり発生に強い影響を与えていると考えられるのは, 西日本において中央構造線沿いに地すべり移動体面積率 （1 km²，地質）の高い地域が線状に分布していること からも想定される。長崎県北松浦半島周辺, 宮崎県鰐塚 山周辺などの地域は，九州の他の地域ではあまり分布し ていない新・古第三紀堆積岩類が分布していることが, 局所的に地すべり移動体面積率 ( $1 \mathrm{~km}^{2}$ ，地質）が高く なっている原因だと推測される（羽田野ほか，1974； Chigira，2009)。一方, 平野部では無く山地であるのに も関わらず地すべり移動体面積率（1 $\mathrm{km}^{2}$, 地質）が低 い地域が, 東北地方東部の岩手・福島の太平洋側, 糸魚 川-静岡構造線の西部の岐阜周辺, 及び中国地方全域に 見られる。この地域の多くは花崗岩類が分布しており， 地すべり地形分布図の判読対象とされる $150 \mathrm{~m}$ 越える 大規模な地すべりがほとんど発生していないことが，地 すべり移動体面積率（1 km²，地質）が低い原因だと推 測される。ただし1972年の愛知県小原村豪雨災害（戸邊 ほか，2007，他）, 1999年広島豪雨災害（黒木·長谷川, 2003，他），2009年山口防府豪雨災害（大丸ほか，2011， 他)，2014年広島土石流災害 (土志田ほか，2014，他)の ような表層崩壊による斜面災害は多く発生していること から, 花崗岩地域は地すべりの発生数が少ないが斜面災 害に対して安全であるというわけではなく, 発生しやす い土砂災害の種類が地すべりとは異なっているだけであ ることを注意しなければならない。

表ー 1 に扔いて地すべり移動体面積率（地質）が高い 地質，低い地質を紹介する。最も高い値を示したのは， ジュラ紀前期（J1) の海成または非海成堆積岩類（地 質番号：260, 地質コード：J 1 sr）の $39.3 \%$ あるる。 J 1 srは，そのほとんどが糸魚川ー静岡構造線の北限（日本 海周辺）に分布している。その地質全体の面積は解析範 囲内で $136.3 \mathrm{~km}^{2}$ であり, 解析範囲全体における $0.039 \%$ の面積でしかない。本地質の地すべり移動体面積率（地 質）が高い原因は，地質及び地質構造によるものか，構 造運動によるものか, その判断は難しい。解析範囲にお いて全体の $0.1 \%$ 以上の面積 $\left(353.5 \mathrm{~km}^{2}\right)$ を持つ地質体
のうち，地すべり移動体面積率（地質）が高かったのは， 後期漸新世 - 前期中新世 (PG 4 ) の非アルカリ苦鉄質 火山岩類（地質番号：1060, 地質コード：PG $4 \mathrm{vb）の}$ $20.3 \%$ (地質面積 $679.6 \mathrm{~km}^{2}$ )，御荷鉾緑色岩類（苦鉄質 岩部)（地質番号：1640, 地質コード：M13plb）の19.1\% (地質面積 $567.3 \mathrm{~km}^{2}$ ), 超苦鉄質岩類（超塩基性岩：蛇 紋岩：オフイオライト)(地質番号： 555 , 地質コード： $\mathrm{Uu}$ ）の $18.7 \%$ (地質面積 $1691.7 \mathrm{~km}^{2}$ ) などが挙げられる。 特に超苦鉄質岩類（Uu）は全国に広く分布していなが ら地すべり移動体面積率（地質）が高い值を示している ことから，地すべり移動体分布は地質の影響を強く受け ていることが推測される。

地すべり移動体面積率（地質）が低い值（0.1\%以下） を示した地質体は数多く存在したが，そのなかで地質面 積が解析範囲全体の $0.1 \%$ 以上の面積 $\left(353.5 \mathrm{~km}^{2}\right)$ を持 つものは 19 地質体存在した。そのうち $0.3 \%$ 以上の面積 $\left(1,060.5 \mathrm{~km}^{2}\right)$ を持つものは10地質体であった。これら 地すべり移動体面積率（地質）が低い地質体をまとめる と, 人工改変地および後期更新世から完新世の堆積物, 花崗岩類，そして一部の変成岩類が挙げられる。

全体的な傾向として年代・岩相区分別に地すべり移動 体面積率（地質）を見ると，新第三紀の地質で地すべり 移動体面積率（地質）は高くなり，第四紀の岩相や古第 三紀以前の岩相（高圧タイプの変成岩類を除く）におい ては相対的に地すべり移動体面積率（地質）は低くなっ ている。岩相的には堆積岩類, 火山岩類, 高圧タイプの 変成岩類，蛇紋岩などの苦鉄質岩類で地すべり移動体面 積率（地質）は高い值を示す一方, 深成岩類, 高温夕イ プの変成岩類においては低い值を示した。付加コンプ レックスの基本的な傾向として地すべり移動体面積率 （地質）は低い值を示すが，一部の岩相（ジュラ紀後期 一白亜紀前期（J 3-K 1) の付加コンプレックスの玄武 岩ブロック (ペルム紀) (地質番号：457,地質コード : J $3-\mathrm{K} 1 \mathrm{ad})$, 後期白亜紀後期 - 前期漸新世 (K22-PG 3 ) の付加コンプレックスの基質（地質番号 : 490, 地質コー ド : K22-PG $3 \mathrm{ax}$ ), 中期始新世 - 前期漸新世 (PG 2-PG 3 ）の付加コンプレックスの基質（地質番号： 500, 地質 コード：PG 2-3 ax）などにおいて $10.4 \%$ 以上と平均値 の倍以上の高い值を示している。そのため, 付加コンプ レックスにおいて一概に過去に発生した地すべりが少な いわけではない（横山，2010）。これらの傾向は，地質 によって地すべり移動体面積率（地質）が強く影響を受 けていることを示している。日本全国の地すべり指定地 を対象とした研究（新井場ほか，2008）では新第三紀・ 古第三紀堆積岩において最も多く地すべり指定地が分布 しているとされているが，これは新第三紀・古第三紀を まとめて分類しているためである。

上記の内容は今まで定性的に考元られていた, 地す心゙ りが多く発生する地質, ほとんど発生しない地質と一致 する。今まで定性的でしか述べられていなかった地すべ 
表－1－1 地すべり分布の地質・地質面積・移動体面積・地すべり移動体面積率（地質）

Table 1-1 Geological unit, area of geological unit, area of landslide and landslide body ratio

\begin{tabular}{|c|c|c|c|c|c|}
\hline 地質番号 & 地質コード & $\begin{array}{c}\text { 地質面積 } \\
{\left[\mathrm{km}^{2}\right]}\end{array}$ & $\begin{array}{c}\text { 移動体面積 } \\
{\left[\mathrm{km}^{2}\right]}\end{array}$ & $\begin{array}{c}\text { 地すべり移動体 } \\
\text { 面積率 [\%] }\end{array}$ & 地質名 \\
\hline 1 & $\mathrm{Hrl}$ & 1776.4 & 0.2 & 0 & 完新世(H)の人工改変地 \\
\hline 2 & $\mathrm{Hla}$ & 103.7 & 1.6 & 1.5 & 後期更新世-完新世(H)の湖成層 \\
\hline 3 & $\mathrm{Hfn}$ & 3860.7 & 220.2 & 5.7 & 後期更新世-完新世(H)の扇状地(含: 崖錐)堆積物 \\
\hline 4 & Hsw & 1811.9 & 2.6 & 0.1 & 後期更新世-完新世(H)の湿地堆積物 \\
\hline 5 & Hls & 0 & 0 & 0 & 後期更新世-完新世(H)の隆起礁成堆積物 \\
\hline 6 & Hlv & 1556.3 & 2 & 0.1 & 後期更新世-完新世(H)の自然堤防(含: 浜堤)堆積物 \\
\hline 7 & Hsd & 1196.3 & 5.1 & 0.4 & 後期更新世-完新世(H)の砂丘堆積物 \\
\hline 8 & $\mathrm{Hgl}$ & 5.2 & 0.1 & 2.1 & 後期更新世-完新世(H)の永河堆積物 \\
\hline 10 & $\mathrm{Hsr}$ & 37778.1 & 251.7 & 0.7 & 後期更新世-完新世(H)の海成または非海成堆積岩類 \\
\hline 20 & Q3sr & 1286.4 & 44.2 & 3.4 & 後期更新世(Q3)の海成または非海成堆積岩類 \\
\hline 21 & Q2-3ls & 0 & 0 & 0 & 中-後期更新世(Q2-3)の石灰岩(琉球石灰岩) \\
\hline 22 & Q3tl & 9408.9 & 114.4 & 1.2 & 後期更新世(Q3)の低位段丘堆積物 \\
\hline 23 & Q3tm & 5748.2 & 56.8 & 1 & 後期更新世(Q3)の中位段丘堆積物 \\
\hline 24 & Q2th & 3678.5 & 64.1 & 1.7 & 中期更新世(Q2)の高位段丘堆積物 \\
\hline 30 & Q2sr & 3213 & 110.7 & 3.4 & 中期更新世(Q2)の海成または非海成堆積岩類 \\
\hline 31 & Q1-2Is & 108.8 & 19.9 & 18.3 & 前-中期更新世(Q1-2)の石灰岩(琉球石灰岩) \\
\hline 40 & Q1sr & 5209.2 & 257.9 & 5 & 前期更新世(Q1)の海成または非海成堆積岩類 \\
\hline 50 & N3sn & 12858.4 & 1106 & 8.6 & 後期中新世-鮮新世(N3)の海成または非海成堆積岩類 \\
\hline 60 & N2sn & 13018.9 & 1659.7 & 12.7 & 中-後期中新世(N2)の海成または非海成堆積岩類 \\
\hline 70 & $\mathrm{~N} 2-3 \mathrm{sm}$ & 1063.7 & 140.7 & 13.2 & 中期中新世-鮮新世(N2-3)の海成堆積岩類 \\
\hline 80 & $\mathrm{~N} 1 \mathrm{sr}$ & 10182 & 1304.2 & 12.8 & 前期中新世-中期中新世(N1)の海成または非海成堆積岩類 \\
\hline 81 & $\mathrm{~N} 1 \mathrm{sr}$ & 774.1 & 52.1 & 6.7 & 前期中新世-中期中新世(N1)の海成または非海成の砂岩層 \\
\hline 90 & PG4sr & 1670.5 & 202.6 & 12.1 & 後期漸新世-前期中新世(PG4)の海成または非海成堆積岩類 \\
\hline 100 & PG3sr & 2524.8 & 180.1 & 7.1 & 後期始新世-前期漸新世(PG3)の海成または非海成堆積岩類 \\
\hline 110 & PG2sr & 1637.1 & 125 & 7.6 & 中期始新世(PG2)の海成または非海成堆積岩類 \\
\hline 120 & PG2-4sm & 37.1 & 1.9 & 5.2 & 中期始新世-前期中新世(PG2-4)の海成堆積岩類 \\
\hline 130 & PG1sr & 523.3 & 14.5 & 2.8 & 暁新世-前期始新世(PG1)の海成または非海成堆積岩類 \\
\hline 134 & PG1sm & 301.5 & 4.6 & 1.5 & 暁新世-前期始新世(PG1)の海成堆積岩類 \\
\hline 140 & $\mathrm{~K} 2 \mathrm{sn}$ & 244.6 & 15.7 & 6.4 & 白亜紀後期(K2)の非海成堆積岩類 \\
\hline 141 & K2ng & 16.8 & 0.5 & 3.1 & 白亜紀後期(K2)の非海成礫岩層 \\
\hline 143 & K2nt & 15.7 & 0.1 & 0.4 & 白亜紀後期(K2)の非海成砂岩優勢砂岩泥岩互層 \\
\hline 146 & $\mathrm{~K} 2 \mathrm{~nm}$ & 52 & 0.9 & 1.7 & 白亜紀後期(K2)の非海成泥岩層 \\
\hline 160 & $\mathrm{~K} 2 \mathrm{sm}$ & 909.5 & 36.5 & 4 & 後期白亜紀(K2)の海成堆積岩類 \\
\hline 161 & $\mathrm{~K} 22 \mathrm{~ms}$ & 144.6 & 26.9 & 18.6 & 後期白亜紀後期(K22)の海成砂岩優勢層 \\
\hline 162 & K22me & 126.8 & 5 & 3.9 & 後期白亜紀後期(K22)の海成砂岩泥岩互層 \\
\hline 163 & K22mf & 1427.8 & 187 & 13.1 & 後期白亜紀後期(K22)の海成泥岩優勢砂岩泥岩互層 \\
\hline 171 & $\mathrm{~K} 2 \mathrm{mg}$ & 145 & 3.9 & 2.7 & 後期白亜紀(K2)の海成碟岩層 \\
\hline 172 & $\mathrm{~K} 2 \mathrm{mt}$ & 754.9 & 46.5 & 6.2 & 後期白亜紀(K2)の海成砂岩優勢砂岩泥岩互層 \\
\hline 173 & $\mathrm{~K} 2 \mathrm{me}$ & 491.4 & 42.6 & 8.7 & 後期白亜紀(K2)の海成砂岩泥岩互層 \\
\hline 174 & $\mathrm{~K} 2 \mathrm{mf}$ & 314 & 16.4 & 5.2 & 後期白亜紀(K2)の海成泥岩優勢砂岩泥岩互層 \\
\hline 175 & $\mathrm{~K} 2 \mathrm{~mm}$ & 143.9 & 2.1 & 1.4 & 後期白亜紀(K2)の海成泥岩層(周縁相) \\
\hline 181 & $\mathrm{~K} 21 \mathrm{mt}$ & 283.6 & 23.2 & 8.2 & 後期白亜紀前期(K21)の海成砂岩優勢砂岩泥岩互層 \\
\hline 182 & K21me & 692.8 & 91 & 13.1 & 後期白亜紀前期(K21)の海成砂岩泥岩互層 \\
\hline 183 & $\mathrm{~K} 21 \mathrm{~mm}$ & 598.4 & 61.4 & 10.3 & 後期白亜紀前期(K21)の海成泥岩優勢層 \\
\hline 190 & $\mathrm{~K} 1 \mathrm{sn}$ & 607.3 & 96.4 & 15.9 & 白亜紀前期(K1)の非海成堆積岩類 \\
\hline 200 & K12sn & 259.4 & 2.2 & 0.8 & 前期白亜紀後期(K12)の非海成堆積岩類 \\
\hline 210 & K11sn & 139.9 & 2.3 & 1.7 & 前期白带紀前期(K11)の非海成堆積岩類 \\
\hline 211 & K11ns & 173.1 & 41 & 23.7 & 前期白亜紀前期(K11)の非海成砂岩層 \\
\hline 212 & K11nt & 50.8 & 19.4 & 38.2 & 前期白带紀前期(K11)の非海成砂岩優勢砂岩泥岩互層 \\
\hline 213 & K11ne & 26 & 8 & 30.6 & 前期白亜紀前期(K11)の非海成等量砂岩泥岩互層 \\
\hline 214 & $\mathrm{~K} 11 \mathrm{nf}$ & 50.3 & 11.4 & 22.6 & 前期白重紀前期(K11)の非海成泥岩優勢砂岩泥岩層 \\
\hline 220 & $\mathrm{~K} 1 \mathrm{sr}$ & 70.6 & 10.5 & 14.9 & 白亜紀前期(K1)の海成または非海成堆積岩類 \\
\hline 230 & $\mathrm{~K} 1 \mathrm{sm}$ & 663.2 & 19.7 & 3 & 前期白亜紀(K1)の海成堆積岩類 \\
\hline 231 & $\mathrm{~K} 1 \mathrm{mg}$ & 37.8 & 0.8 & 2.1 & 前期白亜紀(K1)の海成礫岩層 \\
\hline 232 & $\mathrm{~K} 1 \mathrm{mt}$ & 60.4 & 3.9 & 6.4 & 前期白亜紀(K1)の海成砂岩優勢砂岩泥岩互層 \\
\hline 233 & K1me & 132 & 9.2 & 7 & 前期白亜紀(K1)の海成砂岩泥岩互層 \\
\hline 234 & K1mf & 404.8 & 32.1 & 7.9 & 前期白亜紀(K1)の海成泥岩優勢層 \\
\hline 240 & $\mathrm{~J} 2-3 \mathrm{sr}$ & 95.2 & 3.9 & 4 & ジュラ紀中-後期(J2-3)の海成または非海成堆積岩類 \\
\hline 250 & $\mathrm{~J} 2-3 \mathrm{sm}$ & 406.9 & 25.2 & 6.2 & ジュラ紀中-後期(J2-3)の海成堆積岩類 \\
\hline 251 & $\mathrm{~J} 2-3 \mathrm{sm}$ & 4 & 0 & 0 & ジュラ紀中-後期(J2-3)の海成砶岩層 \\
\hline 252 & $\mathrm{~J} 2-3 \mathrm{sm}$ & 2.7 & 0 & 0 & ジュラ紀中-後期(J2-3)の海成砂岩優勢層 \\
\hline 253 & J2-3sm & 50.4 & 0.1 & 0.2 & ジュラ紀中-後期(J2-3)の海成泥岩優勢層 \\
\hline 260 & $\mathrm{~J} 1 \mathrm{sr}$ & 136.3 & 53.6 & 39.3 & ジュラ紀前期(J1)の海成または非海成堆積岩類 \\
\hline 270 & $\mathrm{~J} 1 \mathrm{sm}$ & 55.2 & 5 & 9 & ジュラ紀前期(J1)の海成堆積岩類 \\
\hline 280 & TR2-3sr & 245.9 & 3 & 1.2 & 三盢紀中-後期(TR2-3)の海成または非海成堆積岩類 \\
\hline 281 & TR3sr & 0.1 & 0 & 0 & 三畳紀後期(TR3)の海成または非海成堆積岩類 \\
\hline 290 & TR2-3sm & 147.2 & 10.5 & 7.2 & 三疊紀中-後期(TR2-3)の海成堆積岩類 \\
\hline 291 & TR2-3ms & 11.1 & 0 & 0.1 & 三疊紀中-後期(TR2-3)の海成砂岩優勢層 \\
\hline 292 & TR2-3mm & 6.8 & 0 & 0 & 三疊紀中-後期(TR2-3)の海成泥岩優勢層 \\
\hline 300 & TR1-2sm & 189.3 & 1.4 & 0.8 & 三曽紀前-中期(TR1-2)の海成堆積岩類 \\
\hline
\end{tabular}


表-1-2 地すべり分布の地質・地質面積・移動体面積・地すべり移動体面積率（地質）

Table 1-2 Geological unit, area of geological unit, area of landslide and landslide body ratio

\begin{tabular}{|c|c|c|c|c|c|}
\hline 地質番号 & 地質コード & $\begin{array}{c}\text { 地質面積 } \\
{\left[\mathrm{km}^{2}\right]}\end{array}$ & $\begin{array}{c}\text { 移動体面積 } \\
{\left[\mathrm{km}^{2}\right]}\end{array}$ & $\begin{array}{c}\text { 地すべり移動体 } \\
\text { 面積率 }[\%]\end{array}$ & 地質名 \\
\hline 301 & TR1-2ms & 52.8 & 0.3 & 0.6 & 三畳紀前-中期(TR1-2)の海成砂岩優勢層 \\
\hline 302 & TR1-2mm & 330.2 & 0.9 & 0.3 & 三畳紀前-中期(TR1-2)の海成泥岩優勢層 \\
\hline 310 & Psm & 2524.9 & 40 & 1.6 & ペルム紀(P)の海成堆積岩類 \\
\hline 311 & Pms & 41.5 & 0.5 & 1.2 & ペルム紀(P)の海成砂岩層 \\
\hline 312 & $\mathrm{Pml}$ & 93.3 & 0.9 & 1 & ペルム紀(P)の石灰岩層 \\
\hline 313 & Pmg & 100.9 & 0.5 & 0.5 & ペルム紀(P)の海成碟岩層 \\
\hline 320 & Csm & 213.1 & 2.9 & 1.4 & 石炭紀(C)の海成堆積岩類 \\
\hline 321 & Cms & 104.4 & 0.4 & 0.4 & 石炭紀(C)の海成砂岩層 \\
\hline 322 & $\mathrm{Cml}$ & 1.1 & 0 & 0 & 石炭紀(C)の石灰岩層 \\
\hline 330 & Dsm & 61.4 & 0.4 & 0.7 & デボン紀(D)の海成堆積岩類 \\
\hline 340 & S-Dsm & 19.9 & 0.7 & 3.4 & シルル紀-デボン紀(S-D)の海成堆積岩類 \\
\hline 350 & Ssm & 0.9 & 0 & 0 & シルル紀(S)の海成堆積岩類 \\
\hline 410 & Pax & 1867.1 & 76.9 & 4.1 & ペルム紀(P)の付加コンプレックスの基質 \\
\hline 411 & Pas & 369.7 & 2.5 & 0.7 & ペルム紀(P)の付加コンプレックスの砂岩層 \\
\hline 417 & $\mathrm{Pab}$ & 434.5 & 11 & 2.5 & ペルム紀(P)の付加コンプレックスの玄武岩ブロック(石炭紀-ペルム紀) \\
\hline 418 & Pal & 277.2 & 6.7 & 2.4 & ペルム紀(P)の付加コンプレックス中の石灰岩ブロック(石炭紀-ペルム紀) \\
\hline 419 & Pac & 97 & 2.8 & 2.9 & ペルム紀(P)の付加コンプレックス中のチャートブロック(石炭紀-ペルム紀) \\
\hline 420 & $J 1-2 a x$ & 3016.3 & 124.5 & 4.1 & ジュラ紀前-中期(J1-2)の付加コンプレックスの基質 \\
\hline 421 & J1-2as & 949.4 & 53.3 & 5.6 & ジュラ紀前-中期(J1-2)の付加コンプレックスの砂岩層 \\
\hline 427 & $\mathrm{~J} 1-2 \mathrm{ab}$ & 557.4 & 19.9 & 3.6 & ジュラ紀前-中期(J1-2)の付加コンプレックスの玄武岩ブロック(石炭紀-ペルム紀) \\
\hline 428 & $\mathrm{~J} 1-2 \mathrm{al}$ & 120.9 & 14.3 & 11.9 & ジュラ紀前-中期(J1-2)の付加コンプレックスの石灰岩ブロック(石炭紀-ペルム紀) \\
\hline 429 & $\mathrm{~J} 1-2 \mathrm{ac}$ & 444.6 & 15.7 & 3.5 & ジュラ紀前-中期(J1-2)の付加コンプレックスのチャートブロック(石炭紀-三畳紀後期) \\
\hline 430 & $J 1-3 a x$ & 7211 & 306.7 & 4.3 & ジュラ紀前-後期(J1-3)の付加コンプレックスの基質 \\
\hline 431 & $\mathrm{~J} 1-3$ as & 1150.8 & 39.6 & 3.4 & ジュラ紀前-後期(J1-3)の付加コンプレックスの砂岩層 \\
\hline 437 & $J 1-3 a b$ & 574.7 & 55.4 & 9.6 & ジュラ紀前-後期(J1-3)の付加コンプレックスの玄武岩ブロック(石炭紀-ペルム紀) \\
\hline 438 & $\mathrm{~J} 1-3 \mathrm{al}$ & 305.8 & 20.2 & 6.6 & ジュラ紀前-後期(J1-3)の付加コンプレックスの石灰岩ブロック(石炭紀-ペルム紀) \\
\hline 439 & $\mathrm{~J} 1-3 \mathrm{ac}$ & 1453.4 & 72.7 & 5 & ジュラ紀前-後期(J1-3)の付加コンプレックスのチャートブロック(石炭紀-ジュラ紀中期) \\
\hline 440 & J2-3ax & 4674.6 & 115.7 & 2.5 & ジュラ紀中-後期(J2-3)の付加コンプレックスの基質 \\
\hline 441 & J2-3as & 2630.9 & 104 & 4 & ジュラ紀中-後期(J2-3)の付加コンプレックスの砂岩層 \\
\hline 442 & J2-3af & 225 & 4.9 & 2.2 & ジュラ紀中-後期(J2-3)の付加コンプレックスの泥岩優勢砂岩泥岩互層 \\
\hline 447 & $\mathrm{~J} 2-3 \mathrm{ab}$ & 63.8 & 3 & 4.7 & ジュラ紀中-後期(J2-3)の付加コンプレックスの玄武岩ブロック(石炭紀-ペルム紀) \\
\hline 448 & $\mathrm{~J} 2-3 \mathrm{al}$ & 30.9 & 0.3 & 1.1 & ジュラ紀中-後期(J2-3)の付加コンプレックスの石灰岩ブロック(石炭紀-ペルム紀) \\
\hline 449 & J2-3ac & 1338.8 & 25.6 & 1.9 & ジュラ紀中-後期(J2-3)の付加コンプレックスのチャートブロック（三曽紀-ジュラ紀中期） \\
\hline 450 & $\mathrm{~J} 3-\mathrm{K} 1 \mathrm{ax}$ & 511.9 & 29.3 & 5.7 & ジュラ紀後期-白亜紀前期(J3-K1)の付加コンプレックスの基質 \\
\hline 451 & $\mathrm{~J} 3-\mathrm{K} 1$ as & 52.4 & 1.5 & 2.9 & ジュラ紀後期-白亜紀前期(J3-K1)の付加コンプレックスの砂岩層 \\
\hline 457 & $\mathrm{~J} 3-\mathrm{K} 1 \mathrm{ab}$ & 550.2 & 95 & 17.3 & ジュラ紀後期-白亜紀前期(J3-K1)の付加コンプレックスの玄武岩ブロック(ペルム紀) \\
\hline 458 & $\mathrm{~J} 3-\mathrm{K} 1 \mathrm{al}$ & 138.2 & 6.4 & 4.6 & ジュラ紀後期-白亜紀前期(J3-K1)の付加コンプレックスの石灰岩ブロック(ペルム紀-白亜紀前期) \\
\hline 459 & $\mathrm{~J} 3-\mathrm{K} 1 \mathrm{ac}$ & 157.9 & 5.8 & 3.7 & ジュラ紀後期-白亜紀前期(J3-K1)の付加コンプレックスのチャートブロックペルム紀-白亜紀前期) \\
\hline 460 & $\mathrm{~K} 1-2 \mathrm{ax}$ & 693.3 & 50.1 & 7.2 & 白亜紀前期-後期(K1-2)の付加コンプレックスの基質 \\
\hline 461 & K1-2ag & 6 & 0.1 & 2.1 & 白亜紀前期-後期(K1-2)の付加コンプレックスの磁岩層 \\
\hline 462 & $\mathrm{~K} 1-2 \mathrm{as}$ & 624.3 & 27.2 & 4.4 & 白亜紀前期-後期(K1-2)の付加コンプレックスの砂岩層 \\
\hline 463 & K1-2at & 967.2 & 11.5 & 1.2 & 白带紀前期-後期(K1-2)の付加コンプレックスの砂岩優勢砂岩泥岩互層 \\
\hline 464 & K1-2ae & 972 & 12 & 1.2 & 白亜紀前期-後期(K1-2)の付加コンプレックスの等量砂岩泥岩互層 \\
\hline 465 & K1-2af & 843.5 & 14.5 & 1.7 & 白亜紀前期-後期(K1-2)の付加コンプレックスの泥岩優勢砂岩泥岩互層 \\
\hline 467 & $K 1-2 a b$ & 226.8 & 17 & 7.5 & 白亜紀前期-後期(K1-2)の付加コンプレックスの玄武岩ブロック(ジュラ紀後期-自亜紀前期) \\
\hline 468 & K1-2al & 5.8 & 0.2 & 3.3 & 白亜紀前期-後期(K1-2)の付加コンプレックスの石灰岩ブロック(ジュラ紀後期-白亜紀前期) \\
\hline 469 & K1-2ac & 34.5 & 0.9 & 2.5 & 白亜紀前期-後期(K1-2)の付加コンプレックスのチャートブロック(ジュラ紀後期-白亜紀前期) \\
\hline 470 & $\mathrm{~K} 2 \mathrm{ax}$ & 2562.8 & 113.3 & 4.4 & 白亜紀後期(K2)の付加コンプレックスの基質 \\
\hline 471 & K2ag & 40.3 & 0.4 & 1.1 & 白亜紀後期(K2)の付加コンプレックスの碟岩層 \\
\hline 472 & K2as & 576.2 & 13.6 & 2.4 & 白亜紀後期(K2)の付加コンプレックスの砂岩層 \\
\hline 473 & K2at & 2253.3 & 42.3 & 1.9 & 白带紀後期(K2)の付加コンプレックスの砂岩優勢砂岩泥岩互層 \\
\hline 474 & K2ae & 1336.7 & 44.7 & 3.3 & 白亜紀後期(K2)の付加コンプレックスの等量砂岩泥岩互層 \\
\hline 475 & K2af & 2913.2 & 68.2 & 2.3 & 白带紀後期(K2)の付加コンプレックスの泥岩優勢砂岩泥岩互層 \\
\hline 477 & K2ab & 138.1 & 8 & 5.8 & 白亜紀後期(K2)の付加コンプレックスの玄武岩プロック(白亜紀) \\
\hline 478 & K2al & 3.8 & 0.1 & 2.8 & 白亜紀後期(K2)の付加コンプレックスの石灰岩ブロック(白亜紀) \\
\hline 479 & K2ac & 72.3 & 2.3 & 3.2 & 白亜紀後期(K2)の付加コンプレックス中のチャートブロック(白亜紀) \\
\hline 480 & $\mathrm{~K}-\mathrm{PGax}$ & 2298.1 & 86.7 & 3.8 & 白亜紀-前期古第三紀(K-PG)の付加コンプレックスの基質 \\
\hline 482 & K-PGas & 6.9 & 0 & 0 & 白带紀-前期古第三紀(K-PG)の付加コンプレックスの砂岩層 \\
\hline 484 & K-PGae & 7.3 & 0 & 0.5 & 白亜紀-前期古第三紀(K-PG)の付加コンプレックスの等量砂岩泥岩互層 \\
\hline 485 & K-PGaf & 20.1 & 0.1 & 0.5 & 白带紀-前期古第三紀(K-PG)の付加コンプレックスの泥岩優勢砂岩泥岩互層 \\
\hline 487 & K-PGab & 19.6 & 0.2 & 1.1 & 白业紀-前期古第三紀(K-PG)の付加コンプレックスの玄武岩ブロックペルムム紀-前期白亜紀) \\
\hline 488 & K-PGal & 1.1 & 0.1 & 5.3 & 白亚紀-前期古第三紀(K-PG)の付加コンプレックスの石灰岩ブロックペルム紀-前期白亚紀) \\
\hline 489 & $\mathrm{~K}-\mathrm{PGac}$ & 0.1 & 0 & 0 & 白业紀-前期古第三紀(K-PG)の付加コンプレックスのチャートブロック(ペルム紀-前期白亜紀) \\
\hline 490 & K22-PG3ax & 564.9 & 89.5 & 15.8 & 後期白亜紀後期-前期漸新世(K22-PG3)の付加コンプレックスの基質 \\
\hline 493 & K22-PG3at & 667.4 & 10.5 & 1.6 & 後期白亜紀後期-前期渐新世(K22-PG3)の付加コンプレックスの砂岩優勢砂岩泥岩互層 \\
\hline 495 & K22-PG3af & 1304.7 & 23.5 & 1.8 & 後期白亜紀後期-前期渐新世(K22-PG3)の付加コンプレックスの泥岩優勢砂岩泥岩互層 \\
\hline 497 & K22-PG3ab & 12 & 1 & 8 & 後期白亚紀後期-前期漸新世(K22-PG3)の付加コンプレックスの玄武岩ブロック(白业紀) \\
\hline 500 & PG2-3ax & 592 & 70.5 & 11.9 & 中期始新世-前期漸新世(PG2-PG3)の付加コンプレックスの基質 \\
\hline 501 & PG2-3ag & 23 & 1.1 & 4.8 & 中期始新世-前期漸新世(PG2-PG3)の付加コンプレックスの礫岩層 \\
\hline 502 & PG2-3as & 683.6 & 35.4 & 5.2 & 中期始新世-前期漸新世(PG2-PG3)の付加コンプレックスの砂岩層 \\
\hline
\end{tabular}


表一 1-3 地すべり分布の地質・地質面積・移動体面積・地すべり移動体面積率（地質）

Table 1-3 Geological unit, area of geological unit, area of landslide and landslide body ratio

\begin{tabular}{|c|c|c|c|c|c|}
\hline 地質番号 & 地質コード & $\begin{array}{c}\text { 地質面積 } \\
{\left[\mathrm{km}^{2}\right]}\end{array}$ & $\begin{array}{c}\text { 移動体面積 } \\
{\left[\mathrm{km}^{2}\right]}\end{array}$ & $\begin{array}{c}\text { 地すべり移動体 } \\
\text { 面積率 }[\%]\end{array}$ & 地質名 \\
\hline 503 & PG2-3at & 1019.3 & 70.2 & 6.9 & 中期始新世-前期漸新世(PG2-PG3)の付加コンプレックスの砂岩優勢砂岩泥岩互層 \\
\hline 504 & PG2-3ae & 365.3 & 6.8 & 1.9 & 中期始新世-前期漸新世(PG2-PG3)の付加コンプレックスの等量砂岩泥岩互層 \\
\hline 505 & PG2-3af & 2223.6 & 96.2 & 4.3 & 中期始新世-前期漸新世(PG2-PG3)の付加コンプレックスの泥岩優勢砂岩泥岩互層 \\
\hline 507 & PG2-3ab & 42.6 & 5.7 & 13.3 & 中期始新世-前期潮新世(PG2-PG3)の付加コンプレックスの玄武岩ブロック(曉新世-前期始新世) \\
\hline 510 & PG3-4ax & 1876.3 & 126.1 & 6.7 & 後期始新世-前期中新世(PG3-PG4)の付加コンプレックスの基質 \\
\hline 511 & PG3-4ag & 1.1 & 0 & 0 & 後期始新世-前期中新世(PG3-PG4)の付加コンプレックスの碟岩層 \\
\hline 512 & PG3-4as & 244.2 & 31.6 & 12.9 & 後期始新世-前期中新世(PG3-PG4)の付加コンプレックスの砂岩層 \\
\hline 513 & PG3-4at & 511.9 & 23.7 & 4.6 & 後期始新世-前期中新世(PG3-PG4)の付加コンプレックスの砂岩優勢砂岩泥岩互層 \\
\hline 514 & PG3-4ae & 398 & 4.1 & 1 & 後期始新世-前期中新世(PG3-PG4)の付加コンプレックスの等量砂岩泥岩互層 \\
\hline 515 & PG3-4af & 270.8 & 6.2 & 2.3 & 後期始新世-前期中新世(PG3-PG4)の付加コンプレックスの泥岩優勢砂岩泥岩互層 \\
\hline 517 & PG3-4ab & 22.7 & 2.8 & 12.2 & 後期始新世-前期中新世(PG3-PG4)の付加コンプレックスの玄武岩ブロック(曉新世-中期始新世) \\
\hline 518 & PG3-4al & 29.5 & 2.2 & 7.4 & 後期始新世-前期中新世(PG3-PG4)の付加コンプレックスの石灰岩ブロック(中期始新世-前期潮新世) \\
\hline 550 & PG4av & 3.4 & 1 & 28.1 & 後期漸新世-前期中新世(PG4)の苦鉄質火山岩類(付加コンプレックス中の岩体) \\
\hline 551 & K2av & 22 & 0.6 & 2.9 & 白亜紀後期(K2)の苦鉄質火山岩類(付加コンプレックス中の岩体) \\
\hline 552 & J-K1av & 1081.3 & 52 & 4.8 & ジュラ紀-白亜紀前期(J-K1)の苦鉄質火山岩類(付加コンプレックス中の岩体) \\
\hline 553 & Jav & 310.7 & 89.2 & 28.7 & ジュラ紀(J1-3)の苦鉄質火山岩類(付加コンプレックス中の岩体) \\
\hline 554 & Pav & 365.1 & 6.3 & 1.7 & ペルム紀(P)の苦鉄質火山岩類(付加コンプレックス中の岩体) \\
\hline 555 & $\mathrm{Uu}$ & 1691.7 & 316.4 & 18.7 & 超苦鉄質岩類(超塩基性岩:蛇紋岩:オフィオライト) \\
\hline 556 & PG4ap & 4.5 & 1.6 & 35.2 & 後期漸新世-前期中新世(PG4)の苦鉄質深成岩類(付加コンプレックス中の岩体) \\
\hline 557 & K1ap & 99.1 & 2.1 & 2.1 & 白亜紀前期(K1)の苦鉄質深成岩類(付加コンプレックス中の岩体) \\
\hline 558 & J-K1ap & 25.8 & 1.9 & 7.3 & ジュラ紀-白亜紀前期(J-K1)の苦鉄質深成岩類(付加体コンプレックスの岩体) \\
\hline 559 & Jap & 22.7 & 2.8 & 12.3 & ジュラ紀(J)の苦鉄質深成岩類(付加コンプレックス中の岩体) \\
\hline 560 & Pap & 657.3 & 28.2 & 4.3 & ペルム紀(P)の苦鉄質深成岩類(付加コンプレックス中の岩体) \\
\hline 700 & Hvt & 2282.4 & 21.7 & 0.9 & 完新世 $(H)$ の降下テフラ \\
\hline 710 & Qvd & 3308 & 237.8 & 7.2 & 第四紀(Q)の火山岩隔 \\
\hline 711 & Hvd & 1450.6 & 72.6 & 5 & 完新世(H)の火山岩詹 \\
\hline 712 & Q3vd & 412.1 & 24.8 & 6 & 後期更新世(Q3)の火山岩㞕 \\
\hline 713 & Q2vd & 396.5 & 11.9 & 3 & 中期更新世(Q2)の火山岩㞕 \\
\hline 714 & Q1vd & 68.5 & 10.6 & 15.5 & 前期更新世(Q1)の火山岩屑 \\
\hline 803 & Q1vi & 5 & 0.3 & 6.7 & 前期更新世(Q1)の珪長質火山岩類(非アルカリ貫入岩) \\
\hline 804 & N3vi & 469.1 & 42.7 & 9.1 & 後期中新世-鮮新世(N3)の珪長質火山岩類(非アルカリ貫入岩) \\
\hline 805 & N2vi & 1136.6 & 38.9 & 3.4 & 中-後期中新世(N2)の珪長質火山岩類(非アルカリ貫入岩) \\
\hline 806 & N1vi & 56.6 & 3.4 & 6 & 前期中新世-中期中新世(N1)の珪長質火山岩類(非アルカリ貫入岩) \\
\hline 807 & PG4vi & 43.8 & 6.6 & 15.1 & 後期漸新世-前期中新世(PG4)の珪長質火山岩類(非アルカリ貫入岩) \\
\hline 808 & PG3vi & 6.6 & 0 & 0.1 & 後期始新世-前期漸新世(PG3)の珪長質火山岩類(非アルカリ貫入岩) \\
\hline 809 & PG2vi & 16.4 & 0.2 & 1.4 & 中期始新世(PG2)の珪長質火山岩類(非アルカリ貫入岩) \\
\hline 810 & PG1vi & 110 & 4.4 & 4 & 暁新世-前期始新世(PG1)の珪長質火山岩類(非アルカリ貫入岩) \\
\hline 811 & K2vi & 542 & 20.1 & 3.7 & 白亜紀後期(K2)の珪長質火山岩類(非アルカリ貫入岩) \\
\hline 812 & $\mathrm{~K} 1 \mathrm{vi}$ & 33.5 & 0.2 & 0.7 & 白亜紀前期(K1)の珪長質火山岩類(非アルカリ貫入岩) \\
\hline 820 & Q3-Hvf & 1.4 & 0 & 0 & 後期更新世-完新世(Q3-H)の非アルカリ珪長質火山岩類 \\
\hline 821 & Hvf & 78.2 & 1 & 1.2 & 完新世(H)の非アルカリ珪長質火山岩類 \\
\hline 822 & Q3vf & 162.8 & 4.2 & 2.6 & 後期更新世(Q3)の非アルカリ珪長質火山岩類 \\
\hline 823 & Q2vf & 196.8 & 4.5 & 2.3 & 中期更新世(Q2)の非アルカリ珪長質火山岩類 \\
\hline 824 & Q1vf & 285.4 & 24.5 & 8.6 & 前期更新世(Q1)の非アルカリ珪長質火山岩類 \\
\hline 825 & N3vf & 1807.1 & 110.1 & 6.1 & 後期中新世-鮮新世(N3)の非アルカリ珪長質火山岩類 \\
\hline 826 & N2vf & 3759.8 & 365.5 & 9.7 & 中期中新世-後期中新世(N2)の非アルカリ珪長質火山岩類 \\
\hline 827 & N1vf & 7316.9 & 895 & 12.2 & 前期中新世-中期中新世(N1)の非アルカリ珪長質火山岩類 \\
\hline 828 & PG4vf & 217 & 33 & 15.2 & 後期漸新世-前期中新世(PG4)の非アルカリ珪長質火山岩類 \\
\hline 829 & PG3vf & 161.6 & 1.2 & 0.8 & 後期始新世-前期漸新世(PG3)の非アルカリ珪長質火山岩類 \\
\hline 830 & PG2vf & 313.9 & 3.4 & 1.1 & 中期始新世(PG2)の非アルカリ珪長質火山岩類 \\
\hline 831 & PG1vf & 366 & 52.1 & 14.2 & 暁新世-前期始新世(PG1)の非アルカリ珪長質火山岩類 \\
\hline 832 & K2vf & 11149.9 & 295.1 & 2.6 & 白亜紀後期(K2)の非アルカリ珪長質火山岩類 \\
\hline 833 & K1vf & 147.6 & 3.1 & 2.1 & 白亜紀前期(K1)の非アルカリ珪長質火山岩類 \\
\hline 900 & Q3-Hvp & 51.4 & 2.1 & 4.1 & 後期更新世-完新世(Q3-H)の火山岩類(非アルカリ火砕流) \\
\hline 901 & Hvp & 1977.3 & 65 & 3.3 & 完新世(H)の火山岩類(非アルカリ火砕流) \\
\hline 902 & Q3vp & 9015.9 & 89.1 & 1 & 後期更新世(Q3)の火山岩類(非アルカリ火砕流) \\
\hline 903 & Q2vp & 3113.9 & 81.8 & 2.6 & 中期更新世(Q2)の火山岩類(非アルカリ火砕流) \\
\hline 904 & Q1vp & 3177.6 & 176.8 & 5.6 & 前期更新世(Q1)の火山岩類(非アルカリ火砕流) \\
\hline 905 & N3vp & 2836.7 & 197.5 & 7 & 後期中新世-鮮新世(N3)の火山岩類(非アルカリ火砕流) \\
\hline 906 & N2vp & 845.6 & 63.4 & 7.5 & 中期中新世-後期中新世(N2)の火山岩類(非アルカリ火砕流) \\
\hline 907 & N1vp & 28.1 & 7.4 & 26.4 & 前期中新世-中期中新世(N1)の火山岩類(非アルカリ火砕流) \\
\hline 1000 & Q3-Hvb & 61.5 & 2.8 & 4.6 & 後期更新世-完新世(Q3-H)の非アルカリ苦鉄質火山岩類 \\
\hline 1001 & $\mathrm{Hvb}$ & 1537.6 & 24.2 & 1.6 & 完新世 $(H)$ の非アルカリ苦鉄質火山岩類 \\
\hline 1002 & Q3vb & 1542.5 & 71.6 & 4.6 & 後期更新世(Q3)の非アルカリ苦鉄質火山岩類 \\
\hline 1010 & Q2vb & 5417.4 & 348.2 & 6.4 & 中期更新世(Q2)の非アルカリの苦鉄質火山岩類 \\
\hline 1020 & Q1vb & 5444.9 & 500.5 & 9.2 & 前期更新世(Q1)の非アルカリ苦鉄質火山岩類 \\
\hline 1030 & N3vb & 10535.3 & 778 & 7.4 & 後期中新世-鮮新世(N3)の非アルカリ苦鉄質火山岩類 \\
\hline 1040 & $\mathrm{~N} 2 \mathrm{vb}$ & 8201 & 764.4 & 9.3 & 中期中新世-後期中新世(N2)の非アルカリ苦鉄質火山岩類 \\
\hline 1050 & N1vb & 9224 & 1119.2 & 12.1 & 前期中新世-中期中新世(N1)の非アルカリ苦鉄質火山岩類 \\
\hline 1060 & PG4vb & 679.6 & 137.7 & 20.3 & 後期漸新世-前期中新世(PG4)の非アルカリ苦鉄質火山岩類 \\
\hline
\end{tabular}


表- 1-4 地すべり分布の地質・地質面積・移動体面積・地すべり移動体面積率（地質）

Table 1-4 Geological unit, area of geological unit, area of landslide and landslide body ratio

\begin{tabular}{|c|c|c|c|c|c|}
\hline 地質番号 & 地質コード & $\begin{array}{c}\text { 地啠面皘 } \\
{\left[\mathrm{km}^{2}\right]}\end{array}$ & $\begin{array}{c}\text { 移動体面積 } \\
{\left[\mathrm{km}^{2}\right]}\end{array}$ & $\begin{array}{c}\text { 地すべり移動体 } \\
\text { 面積率 [\% ] }\end{array}$ & 地質名 \\
\hline 1070 & PG3vb & 62.8 & 2.7 & 4.3 & 後期始新世-前期漸新世(PG3)の非アルカリ苦鉄質火山岩類 \\
\hline 1080 & PG2vb & 160.5 & 2.2 & 1.4 & 中期始新世(PG2)の非アルカリの苦鉄質火山岩類 \\
\hline 1100 & $\mathrm{~K} 2 \mathrm{vb}$ & 1239.6 & 20.7 & 1.7 & 白亜紀後期(K2)の非アルカリの苦鉄質火山岩類 \\
\hline 1110 & K1vb & 495.3 & 10.1 & 2 & 白亜紀前期(K1)の非アルカリの苦鉄質火山岩類 \\
\hline 1130 & Q2va & 17.2 & 0.3 & 1.6 & 中期更新世(Q2)のアルカり珪長質火山岩類 \\
\hline 1150 & N3va & 35.7 & 5.7 & 15.9 & 後期中新世-鮮新世(N3)のアルカリ珪長質火山岩類 \\
\hline 1160 & N2va & 91 & 11.4 & 12.5 & 中期中新世-後期中新世(N2)のアルカリ珪長質火山岩類 \\
\hline 1190 & Q3-Hvk & 0 & 0 & 0 & 後期更新世-完新世(Q3-H)のアルカリ苦鉄質火山岩類 \\
\hline 1191 & Hvk & 19.1 & 0.2 & 1.2 & 完新世(H)の苦鉄質火山岩類(アルカリ) \\
\hline 1192 & Q3vk & 135.9 & 1.6 & 1.2 & 後期更新世(Q3)の苦鉄質火山岩類(アルカリ) \\
\hline 1200 & Q2vk & 44.9 & 2.7 & 6.1 & 中期更新世(Q2)のアルカリ苦鉄質火山岩類 \\
\hline 1210 & Q1vk & 112.4 & 1.7 & 1.5 & 前期更新世(Q1)のアルカリ苦鉄質火山岩類 \\
\hline 1220 & N3vk & 199.4 & 3.7 & 1.9 & 後期中新世-鮮新世(N3)のアルカリ苦鉄質火山岩類 \\
\hline 1230 & N2vk & 534.1 & 66.2 & 12.4 & 中期中新世-後期中新世(N2)のアルカリ苦鉄質火山岩類 \\
\hline 1240 & N1vk & 28.6 & 0.9 & 3.1 & 前期中新世-中期中新世(N1)のアルカリ苦鉄質火山岩類 \\
\hline 1260 & N3gp & 305.4 & 33.5 & 11 & 後期中新世-鮮新世(N3)の珪長質深成岩類 \\
\hline 1262 & N3gd & 263.7 & 15.5 & 5.9 & 後期中新世-鮮新世(N3)の花崗閃緑岩 \\
\hline 1263 & Q1gd & 18.7 & 1.7 & 9 & 前期更新世(Q1)の珪長質深成岩類 \\
\hline 1270 & N2gp & 455.3 & 4.3 & 0.9 & 中-後期中新世(N2)の珪長質深成岩類 \\
\hline 1271 & $\mathrm{~N} 2 \mathrm{gr}$ & 141.3 & 1 & 0.7 & 中-後期中新世(N2)の花崗岩 \\
\hline 1272 & N2gd & 918.3 & 21 & 2.3 & 中-後期中新世(N2)の花崗閃緑岩 \\
\hline 1280 & N1gp & 19.5 & 1.7 & 8.7 & 前期漸新世-前期中新世(N1)の珪長質深成岩類 \\
\hline 1281 & N1gr & 265.1 & 8.6 & 3.2 & 前期漸新世-前期中新世(N1)の花崗岩 \\
\hline 1282 & N1gd & 103.1 & 3.3 & 3.2 & 前期漸新世-前期中新世(N1)の花崗閃緑岩 \\
\hline 1290 & PG4gp & 5.3 & 0.2 & 4.6 & 後期漸新世-前期中新世(PG4)の珪長質深成岩類 \\
\hline 1291 & PG4gr & 0 & 0 & 0 & 後期漸新世-前期中新世(PG4)の花崗岩 \\
\hline 1292 & PG4gd & 0 & 0 & 0 & 後期漸新世-前期中新世(PG4)の花崗閃緑岩 \\
\hline 1300 & PG3gp & 0.3 & 0 & 0 & 中期始新世-前期漸新世(PG3)の珪長質深成岩類 \\
\hline 1301 & PG3gr & 97.5 & 0.9 & 0.9 & 中期始新世-前期漸新世(PG3)の花崗岩 \\
\hline 1302 & PG3gd & 55 & 0.9 & 1.6 & 中期始新世-前期漸新世(PG3)の花崗閃緑岩 \\
\hline 1310 & PG2gp & 1.1 & 0 & 0 & 中期始新世(PG2)の珪長質深成岩類 \\
\hline 1311 & PG2gr & 832.6 & 3.2 & 0.4 & 中期始新世(PG2)の花崗岩 \\
\hline 1312 & PG2gd & 4 & 0 & 0 & 中期始新世(PG2)の花崗閃緑岩 \\
\hline 1320 & PG1gp & 1552.7 & 73.4 & 4.7 & 暁新世-前期始新世(PG1)の珪長質深成岩類 \\
\hline 1321 & PG1gr & 1905.9 & 26.7 & 1.4 & 暁新世-前期始新世(PG1)の花崗岩 \\
\hline 1322 & PG1gd & 1473.2 & 15.2 & 1 & 暁新世-前期始新世(PG1)の花崗閃緑岩 \\
\hline 1330 & K2gp & 4265.5 & 154.5 & 3.6 & 白亜紀後期(K2)の珪長質深成岩類(新期領家花崗岩類) \\
\hline 1331 & K2gr & 7106.1 & 90.4 & 1.3 & 白带紀後期(K2)の花崗岩(新期領家花崗岩類) \\
\hline 1332 & K2gd & 2069.9 & 39.2 & 1.9 & 白亜紀後期(K2)の花崗閃緑岩(新期領家花崗岩類) \\
\hline 1340 & K1-2gp & 454.6 & 18.7 & 4.1 & 白亜紀前-後期(K1-2)の珪長質深成岩類(古期領家花崗岩類) \\
\hline 1341 & $\mathrm{~K} 1-2 \mathrm{gr}$ & 1083.7 & 6.8 & 0.6 & 白亜紀前-後期(K1-2)の花崗岩(古期領家花崗岩類) \\
\hline 1342 & K1-2gd & 2653.9 & 32.1 & 1.2 & 白亜紀前-後期(K1-2)の花崗閃緑岩(古期領家花崗岩類) \\
\hline 1350 & $\mathrm{~K} 1 \mathrm{jp}$ & 1129.2 & 25.2 & 2.2 & 白亜紀前期(K1)の阿武隈花崗岩類 \\
\hline 1351 & K1jr & 328.9 & 6.3 & 1.9 & 白亜紀前期(K1)の花崗岩(阿武隈花崗岩類) \\
\hline 1352 & K1jd & 2676.5 & 67.4 & 2.5 & 白亜紀前期(K1)の花崗閃緑岩(阿武隈花崗岩類) \\
\hline 1360 & K1 kp & 838.5 & 16.6 & 2 & 白亜紀前期(K1)の北上花崗岩類 \\
\hline 1361 & $\mathrm{~K} 1 \mathrm{kr}$ & 470 & 4.4 & 0.9 & 白亜紀前期(K1)の花崗岩(北上花崗岩類) \\
\hline 1362 & K1kd & 1685 & 33.2 & 2 & 白亜紀前期(K1)の花崗閃緑岩(北上花崗岩類) \\
\hline 1370 & Jfp & 94.8 & 8.3 & 8.7 & ジュラ紀前期(J)の船津花崗岩類 \\
\hline 1371 & $\mathrm{Jfg}$ & 461.7 & 40.6 & 8.8 & ジュラ紀前期(J)の花崗岩及び花崗閃緑岩(船津花崗岩類) \\
\hline 1372 & $\mathrm{Jfm}$ & 120 & 5.1 & 4.3 & ジュラ紀前期(J)のマイロナイト化した花崗岩類(船津花崗岩類) \\
\hline 1373 & $\mathrm{Jft}$ & 372.9 & 24.7 & 6.6 & ジュラ紀前期(J)のトーナライト(船津花崗岩類) \\
\hline 1374 & $\mathrm{Jfr}$ & 36.8 & 3.8 & 10.3 & ジュラ紀前期(J)のマイロナイト化したトーナライト(船津花崗岩類) \\
\hline 1375 & TR2-3gp & 44.4 & 5.1 & 11.5 & 三盢紀中-後期(TR2-3)の花崗岩類 \\
\hline 1380 & Pfp & 66.1 & 1.3 & 2 & ペルム紀(P)の珪長質深成岩類 \\
\hline 1400 & $\mathrm{PZfp}$ & 73.4 & 0.2 & 0.3 & 古生代(Pz)の深成岩類(珪長質および苦鉄質) \\
\hline 1410 & N3ga & 50.1 & 3.2 & 6.3 & 後期中新世-鮮新世(N3)の苦鉄質深成岩類 \\
\hline 1420 & N2ga & 237.4 & 13.3 & 5.6 & 中-後期中新世(N2)の苦鉄質深成岩類 \\
\hline 1430 & N1 ga & 251.6 & 12.1 & 4.8 & 前-中期新世(N1)の苦鉄質深成岩類 \\
\hline 1440 & PG4ga & 1 & 0 & 0.3 & 後期漸新世-前期中新世(PG4)の苦鉄質深成岩類 \\
\hline 1450 & PG3ga & 68.8 & 0.9 & 1.3 & 後期始新世-前期漸新世(PG3)の苦鉄質深成岩類 \\
\hline 1460 & PG2ga & 244.9 & 6 & 2.5 & 中期始新世(PG2)の苦鉄質深成岩類 \\
\hline 1470 & PG1ga & 104.4 & 1.6 & 1.5 & 暁新世-前期始新世(PG1)の苦鉄質深成岩類 \\
\hline 1480 & K2ga & 264.3 & 5.2 & 2 & 白带紀後期(K2)の苦鉄質深成岩類(新期領家) \\
\hline 1490 & $\mathrm{~K} 1-2 \mathrm{ga}$ & 201 & 4.7 & 2.3 & 白亜紀前-後期(K1-2)の苦鉄質深成岩類(古期領家) \\
\hline 1500 & K1ga & 255.9 & 8.6 & 3.4 & 白亜紀前期(K1)の阿武隈タイプ苦鉄質深成岩類 \\
\hline 1510 & K1ga & 93.9 & 1.8 & 2 & 白亜紀前期(K1)の北上タイプ苦鉄質深成岩類 \\
\hline 1511 & K1ki1 & 48.8 & 0.1 & 0.2 & 白带紀前期(K1)の閃緑岩(北上花崗岩類) \\
\hline 1520 & Jga & 3.8 & 0 & 0 & ジュラ紀(J)の苦鉄質深成岩類 \\
\hline 1530 & Pga & 6.1 & 0.2 & 3.1 & ペルム紀(P)の苦鉄質深成岩類 \\
\hline
\end{tabular}


表一 1-5 地すべり分布の地質・地質面積・移動体面積・地すべり移動体面積率（地質）

Table $1-5$ Geological unit, area of geological unit, area of landslide and landslide body ratio

\begin{tabular}{|c|c|c|c|c|c|}
\hline 地質番号 & 地質コード & $\begin{array}{c}\text { 地質面積 } \\
{\left[\mathrm{km}^{2}\right]}\end{array}$ & $\begin{array}{c}\text { 移動体面積 } \\
{\left[\mathrm{km}^{2}\right]}\end{array}$ & $\begin{array}{c}\text { 地すべり移動体 } \\
\text { 面積率 }[\%]\end{array}$ & 地質名 \\
\hline 1540 & PG3gm & 305.6 & 1.7 & 0.6 & \begin{tabular}{|l|} 
始新世-漸新世(PG3)の深成岩類(ミグマタイト質) \\
\end{tabular} \\
\hline 1551 & M11tum & 414 & 3.1 & 0.7 & 中期始新世-前期中新世の泥質片岩(日高変成岩類) \\
\hline 1552 & M11tub & 64.3 & 0.5 & 0.7 & 中期始新世-前期中新世の苦鉄質片岩(日高変成岩類) \\
\hline 1560 & M8tux & 89.2 & 3.3 & 3.7 & 領家変成岩(m8/低-中圧型) \\
\hline 1561 & M8tlx & 53.3 & 1.3 & 2.4 & 領家変成岩(黒雲母帯-董青石帯) \\
\hline 1562 & M8tlm & 196.1 & 4.5 & 2.3 & 領家変成岩の泥質片麻岩(黒雲母帯-董青石帯) \\
\hline 1563 & M8tlz & 698.2 & 15.2 & 2.2 & 領家変成岩の砂質片麻岩(黒雲母帯-董青石帯) \\
\hline 1564 & M8tlb & 8.4 & 0.3 & 3.8 & 領家変成岩の苦鉄質片麻岩(黒雲母帯-董青石帯) \\
\hline 1565 & M8tII & 2.3 & 0.1 & 4.4 & 領家変成岩の石灰質片麻岩(黒雲母帯-董青石帯) \\
\hline 1566 & M8tlc & 100.2 & 0.8 & 0.8 & 領家変成岩の珪質片麻岩(黒雲母帯-董青石帯) \\
\hline 1567 & M8thx & 215.3 & 7.7 & 3.6 & 領家変成岩(珪線石帯) \\
\hline 1568 & M8thm & 119.9 & 0.9 & 0.7 & 領家変成岩の泥質片麻岩(珪線石帯) \\
\hline 1569 & M8thz & 424.7 & 9.3 & 2.2 & 領家変成岩の砂質片麻岩(珪線石帯) \\
\hline 1570 & M8thb & 1.5 & 0.1 & 6.3 & 領家変成岩の苦鉄質片麻岩(珪線石帯) \\
\hline 1571 & M8thl & 8.5 & 0 & 0 & 領家変成岩の石灰質片麻岩(珪線石帯) \\
\hline 1572 & M8the & 187.4 & 1.8 & 1 & 領家変成岩の珪質片麻岩(珪線石帯) \\
\hline 1580 & M7tux & 44.3 & 1.1 & 2.4 & 阿武隈変成岩(m7/低-中圧型) \\
\hline 1581 & M7tlm & 10.5 & 0 & 0.2 & 阿武隈変成岩の泥質片麻岩(弱変成) \\
\hline 1582 & M7tlb & 34.4 & 0.2 & 0.4 & 阿武隈変成岩の苦鉄質片麻岩(弱変成) \\
\hline 1583 & M7tll & 1.2 & 0 & 0 & 阿武隈変成岩の石灰質片麻岩(弱変成) \\
\hline 1590 & M7tlc & 292.2 & 1.5 & 0.5 & 阿武隈変成岩の珪質片麻岩(弱変成) \\
\hline 1592 & M7thm & 235.8 & 1.5 & 0.6 & 阿武隈変成岩の泥質片麻岩(強変成) \\
\hline 1593 & M7thb & 0.2 & 0 & 3.8 & 阿武隈変成岩の苦鉄質片麻岩(強変成) \\
\hline 1597 & M9pux & 2.7 & 0.5 & 17.8 & 三波川変成岩類(m9/高圧型) \\
\hline 1598 & M9plx & 36.1 & 2.5 & 7 & 三波川変成岩類(弱変成相) \\
\hline 1599 & M9plm & 3265.3 & 364.7 & 11.2 & 三波川変成岩類の泥質片岩(弱変成相) \\
\hline 1600 & M9plz & 264.6 & 31.9 & 12 & 三波川変成岩類の砂質片岩(弱変成相) \\
\hline 1610 & M9plg & 3 & 0.4 & 12.1 & 三波川変成岩類の碟質片岩(弱変成相) \\
\hline 1620 & M9plb & 1051.4 & 111.5 & 10.6 & 三波川変成岩類苦鉄質片岩(弱変成相) \\
\hline 1630 & M9pll & 13 & 2 & 15.6 & 三波川変成岩類の石灰質片岩(弱変成相) \\
\hline 1631 & M9plc & 148.9 & 14.3 & 9.6 & 三波川変成岩類の珪質片岩(弱変成相) \\
\hline 1632 & M9phx & 19.2 & 2.2 & 11.4 & 三波川変成岩類(点紋帯) \\
\hline 1633 & M9phm & 671.8 & 112 & 16.7 & 三波川変成岩類の泥質片岩(点紋帯) \\
\hline 1634 & M9phz & 2.3 & 0.4 & 16.9 & 三波川変成岩類の砂質片岩(点紋帯) \\
\hline 1636 & M9phb & 261.7 & 28.8 & 11 & 三波川変成岩類の苦鉄質片岩(点紋帯) \\
\hline 1637 & M9phl & 0.2 & 0 & 0 & 三波川変成岩類の石灰質片岩(点紋帯) \\
\hline 1638 & M9phc & 43.1 & 7.7 & 17.8 & 三波川変成岩類の珪質片岩(点紋帯) \\
\hline 1639 & M13plz & 56.5 & 7 & 12.3 & 御荷鉾緑色岩類(砂質-泥質岩) \\
\hline 1640 & M13plb & 567.3 & 108.5 & 19.1 & 御荷鉾緑色岩類(苦鉄質岩部) \\
\hline 1641 & M13plc & 18.9 & 4.6 & 24.4 & 御荷鉾緑色岩類(チャート) \\
\hline 1643 & M10pum & 310.1 & 57.2 & 18.5 & カムイコタン変成岩の泥質片岩 \\
\hline 1644 & M10puz & 23.7 & 5.4 & 22.7 & カムイコタン変成岩の砂質片岩 \\
\hline 1645 & M10pub & 232.4 & 40.1 & 17.3 & カムイコタン変成岩の苦鉄質片岩 \\
\hline 1646 & M10pul & 0.7 & 0.1 & 19 & カムイコタン変成岩の石灰質片岩 \\
\hline 1647 & M10puc & 9.2 & 1.5 & 16.2 & カムイコタン変成岩の珪質片岩 \\
\hline 1650 & M6pux & 102 & 1 & 0.9 & 新期三郡(三郡-周防)変成岩類(m6/高圧型) \\
\hline 1651 & M6pum & 579.5 & 15.3 & 2.6 & 新期三郡(三郡-周防)変成岩類の泥質片岩 \\
\hline 1653 & M6pub & 30.1 & 0.9 & 2.8 & 新期三郡(三郡-周防)変成岩類の苦鉄質片岩 \\
\hline 1655 & M6puc & 52.5 & 1.6 & 3 & 新期三郡(三郡-周防)変成岩類の珪質片岩 \\
\hline 1660 & M5pux & 16.2 & 0.5 & 3.3 & 古期三郡(三郡-蓮華)変成岩類(m5/高圧型) \\
\hline 1661 & M5pum & 1463.9 & 15.1 & 1 & 古期三郡(三郡-蓮華)変成岩類の泥質片岩 \\
\hline 1662 & M5puz & 93.8 & 0.4 & 0.4 & 古期三郡(三郡-蓮華)変成岩類の砂質片岩 \\
\hline 1663 & M5pub & 305.3 & 4.8 & 1.6 & 古期三郡(三郡-蓮華)変成岩類の苦鉄質片岩 \\
\hline 1664 & M5pul & 4.5 & 0 & 0.7 & 古期三郡(三郡-蓮華)変成岩類の石灰質片岩 \\
\hline 1665 & M5puc & 36.3 & 0.3 & 0.7 & 古期三郡(三郡-蓮華)変成岩類の珪質片岩 \\
\hline 1670 & M3pux & 71.4 & 10.8 & 15.2 & 長門変成岩類·飛騨外縁構造帯の変成岩 (m3/高圧型) \\
\hline 1671 & M3puz & 50.7 & 0.2 & 0.3 & 長門変成岩類·飛騨外縁構造帯の砂質·泥質片岩 \\
\hline 1672 & M3pub & 210.7 & 2.6 & 1.2 & 長門変成岩類·飛騨外縁構造帯の苦鉄質片岩 \\
\hline 1673 & M3pul & 0.7 & 0 & 0 & 長門変成岩類·飛騨外縁構造帯の石灰質片岩 \\
\hline 1680 & M1tux & 66.3 & 2.2 & 3.3 & 黒瀬川変成岩類(m1/低-中圧型) \\
\hline 1681 & M2pux & 191.7 & 2.4 & 1.3 & 松ヶ平·母体·御齋所·竹貫変成岩(m2/高圧型) \\
\hline 1682 & M4tux & 16.3 & 2.4 & 14.5 & 夜久野変成岩もしくは宇奈月変成岩(m4/低-中圧型) \\
\hline 1683 & Mxtux & 353 & 22.1 & 6.3 & 飛騨変成岩類(mx/低-中圧型) \\
\hline 1684 & Mxtuq & 94.2 & 9.7 & 10.2 & 飛騨帯の石英·長石質片麻岩 \\
\hline 1685 & Mxtub & 94.4 & 9.9 & 10.5 & 飛騨帯の苦鉄質片麻岩 \\
\hline 1700 & Mxtul & 201.7 & 21.1 & 10.5 & 飛騨帯の石灰質片麻岩 \\
\hline 2000 & wt & 3311.1 & 31.1 & 0.9 & 湖水·河川·海など \\
\hline
\end{tabular}


り地形分布の傾向を定量的に示すことができた。また， 「地すべりは，地すべりが過去に発生した地形・地質周 辺で発生しやすい」という前提を踏まえて考察すると， 地すべり移動体面積率（地質）は，各地質における相対 的な地すべり発生危険度を示す 1 つの指標として評価す ることもできる。

\section{5. まとめ・今後の展望}

日本全域を対象とした地すべり地形分布の解析の結果, 定量的な地すべり地形分布の密度評価（地すべり移動体 面積率の算出）を行うことができた。その結果，地すべ り移動体面積率は，地質の年代・岩相によって大きく異 なることが明らかになった。

今回の研究においては，地質のみに特化して地すべり 移動体面積率を算出したが，地すべり発生に強く影響を 与えるのは地質のみならず, 地質構造 - 地形・内部営 力・外部営力など様々なものが考えられる。そのため, 今後はそれぞれのパラメータを組み达んで, 地すべり地 形分布の密度の差異の原因を明らかにしていきたい。ま た，今回は地すべり地形分布と地質との関係について， 日本全域における傾向を定量的に示すことができたが， 局所的に見ると同じ地質や似た地質であっても，地域が 異なる場合に地すべり移動体面積率が大きな差異が表れ る事例もいくつか確認された。この原因についても,他の パラメータを追加することで今後明らかにして行きたい。

\section{謝 辞}

本研究を行うにあたり，防災科学技術研究所の大八木 規夫氏 · 井口隆氏 - 内山庄一郎氏，産業技術総合研究所 の斎藤眞氏 - 川畑大作氏 - 西岡芳晴氏 - 小松原环氏, そ の他様々な皆様にご助言を頂きましたこと，この場を借 りてお礼申し上げます。

\section{引用文献}

新井場公徳・野崎保・鄭怲表・福本安正（2008）：日本の地すべり 指定地分布と地質的特徵についてー全国地すべり指定地調査結 果報告一, 日本地すべり学会誌，44(5), 318-323。

防災科学技術研究所 (2015) : 地すべり地形分布図データベース [http://lsweb1.ess.bosai.go.jp/].

（独）防災科学技術研究所（2014）：地すべり地形分布図第57集「沖 縄県域諸島」，防災科学技術研究所研究資料第 388 号.

Chigira, M (2009) : September 2005 rain-induced catastrophic rockslides on slopes affected by deep-seated gravitational deformations, Kyushu, southern Japan, Engineering Geology, 108, $1-15$.

大丸裕武・多田泰之・村上亘・尾川泰浩（2011）：2009年に山口県 防府市周辺で発生した崩壊の歴史的背景, 砂防学会誌, 64 (4), $52-55$.

土志田正二・井口隆（2010）：GISを用いた四国における地すべり の地形特性の解析, 第49回日本地すべり学会研究発表会講演集, p. $200-201$.

土志田正二 (2012)：大規模崩壊発生危険箇所の推定における地す ベり地形分布図適用の可能性, 砂防学会誌, 65(3), 52-55.

土志田正二・新井場公徳・斎藤狊・川畑大作（2014）：2014年 8 月 20日の豪雨により発生した広島市の斜面崩壊，日本地すべり学 会誌, $51(6), 256-259$.

羽田野誠一 岡部文武・渡辺征子 (1974): 「1/50,000北松地域地す べり地形分類図」の作成, 防災科学技術総合研究報告, $32,3-$ 6.

井口隆（1998）: 澄川地すべりの発生前の地すべり地形と地すべり 変動, 日本地すべり学会誌, 35(2), 11-19.

黒木貴一・長谷川裕之（2003）：1999年広島豪雨による斜面崩壊と 斜面地形との関係：観音台地区を例として，応用地質 44 (2)，84 $-93$.

黒田和男 (2002)：地すべりのための地質区分, 深田研ライブラリー, No. 34, p. 58 .

望月巧一（1977）：断層沿いの地すべり：長野県北部, 中山, 小谷, 持京断層上の例，地すべり，13(4)，11-18.

望月巧一・中村三郎（1977）：長野県北部山地に扔ける地すべり地 の分類, 地すべり, 14(2), 4-11.

(社) 日本地すべり学会 (2004)：地すべり一地形地質的認識と用語 一, (社) 日本地すべり学会, p. 318 .

大八木規夫・池田浩子（1998）：地すべり構造と広域場からみた澄 川地すべり，地すべり，35(2), 1-10.

大八木規夫 (2007)：地すべり地形の判読法, 防災科学技術ライブ ラリーVol.1, 近未来社, p. 320 .

大八木規夫 - 内山庄一郎 · 土志田正二 (2013) : 蛇紋岩体分布地域 の地すべり・地すべり地形：その島弧日本列島における概観お よび小滝地区の例，公益財団法人深田地質研究所年報， 14,77 $-118$.

(独) 産業技術総合研究所地質調查総合センター（編）(2014）：20万 分の 1 日本シームレス地質図2014年 1 月14日版.

清水文健（1983）：空中写真による地すべり地形の認定と表現方法, 地すべり, 19(3), 10-18.

鈴木隆介（2006）：蛇紋岩山地に特有の地形学的特徵の形成過程, 地形，27(4)，417-460.

戸邊勇人・千木良雅弘・土志田正二 (2007) : 愛知県旧小原村の風 化花崗岩類における崩壊発生密度の岩相間での比較, 応用地質 48(2), $66-79$.

山岸宏光（編著）(2012）：北海道地すべり地形デジタルマップ，北 海道大学出版会, p. 102.

横山俊治（2010）：付加体地すべりにおける地すべりの初生と初生 地すべり，一般社団法人応用地質学会平成 22 年度特別講演求よ びシンポジウム予稿集，15-22.

（原稿受付2015年 4 月 8 日，原稿受理2015年 7 月17日） 